\title{
Przyczyny pęknięć osi napędnych oraz tocznych pojazdów w eksploatacji
}

\begin{abstract}
$W$ artykule przedstawiono przyczyny pęknięć osi pojazdów trakcyjnych oraz tocznych $w$ eksploatacji. Artykut zostat opracowany w ramach projektu badawczorozwojowego $\mathrm{nr} R 10$ 004806/2009 pt. „Mikroprocesorowy system diagnostyczny głównych systemów trakcyjnego pojazdu szynowego uwzględniajacy ocene bieżaca i prognozowanie stanów”, finansowanego z budżetu Ministerstwa Nauki i Szkolnictwa Wyższego.
\end{abstract}

\section{WSTĘP}

Oś zestawu kołowego należy do jednych $\mathrm{z}$ najbardziej obciążonych elementów pojazdu szynowego $[1,3 \div 8]$, dlatego też tak poważne znaczenie ma prawidłowe utrzymanie zestawu kołowego w procesie eksploatacji. Drugim czynnikiem decydującym o niezawodności osi zestawu kołowego jest przeprowadzenie prawidłowych kontroli diagnostycznych, polegających na stosowaniu badań nieniszczących przez wykwalifikowany i certyfikowany personel. Do podstawowych badań diagnostycznych, które należy stosować dla osi zestawów kołowych należą badania ultradźwiękowe oraz badania magnetoskopowe. Badania te powinny być wykonywane wg instrukcji opracowanych przez producenta osi i zatwierdzonych przez użytkownika pojazdu. Pewnym postępem konstrukcyjnym w zakresie dostępności poszczególnych obszarów osi do badań ultradźwiękowych jest stosowanie osi drążonych, w wyniku czego można przeprowadzić badania szczegółowe, nawet podczas eksploatacji po odkręceniu pokryw maźniczych. Osie drążone są bardziej pracochłonne w wykonaniu, a naprężenia dopuszczalne dla przekrojów osi drążonych są mniejsze aniżeli w przypadku osi pełnych. W przypadku osi pełnych można wykonać w zależności od rodzaju naprawy czy przeglądu, a zatem dostępności poszczególnych fragmentów osi następujące rodzaje badań ultradźwiękowych tzn.:

$\Rightarrow$ badania uproszczone

$\Rightarrow$ badania częściowo uproszczone

$\Rightarrow$ badania szczegółowe.

Aby oś zestawu kołowego była niezawodna w eksploatacji musi być spełnionych szereg warunków . I tak:

$\Rightarrow$ właściwe zaprojektowanie osi zgodnie z normą PN-EN 13103:2011+A1 [12] (pojazdy toczne oraz PN-EN 13104+A1 [13] (pojazdy trakcyjne)

$\Rightarrow$ właściwe wykonanie osi zgodnie $\mathrm{z}$ wytycznymi PN-EN 13261:2011+A1[15]
$\Rightarrow$ prawidłowe wykonanie zestawu kołowego zgodnie z wytycznymi PN-EN 13260:2011+A1 [14]

$\Rightarrow$ utrzymanie osi zgodnie $\mathrm{z}$ wytycznymi PN-EN 15315:2010 [19].

Jak wykazuje praktyka eksploatacyjna bezpieczeństwa osi nie można rozpatrywać w oderwaniu od staniu i utrzymania innych sąsiadujących elementów do jakich należą koła, tarcze hamulcowe łożyska wraz z korpusami maźnic, koła zębate. W przypadku spełnienia ww. wymogów można oczekiwać, że oś zestawu kołowego wykaże dużą żywotność bez potrzeby jej wymiany na nową.

\section{PRZYCZYNY PĘKNIĘĆ OSI TOCZNYCH ORAZ NAPECDNYCH}

\subsection{Uwagi ogólne}

Przyczyny pęknięć osi tocznych oraz napędnych, które pojawiają się z eksploatacji komerycjnej wynikają z następujących czynników:

$\Rightarrow$ obecności wad wewnętrznych w strukturze wewnętrznej osi oraz wad zewnętrznych na powierzchni osi

$\Rightarrow$ braku właściwego zabezpieczenia korozyjnego, w wyniku czego poszczególne powierzchnie osi są narażone na działanie agresywnych tlenków $\mathrm{SO}, \mathrm{SO}_{2}, \mathrm{CO}$ oraz $\mathrm{CO}_{2}$ oraz innych czynników chemicznych, wywołujących korozję

$\Rightarrow$ braku odpowiedniej chropowatości osi w poszczególnych strefach osi

$\Rightarrow$ zatarcie łożyska (łożysk)

$\Rightarrow$ wykonywania niedopuszczalnych operacji cieplnych, przeprowadzonymi w strukturze osi w celach naprawczych np. napawanie

$\Rightarrow$ uderzeniami mechanicznymi podczas napraw lub przeglądów okresowych, powstałymi w sposób niezamierzony wskutek niewłaściwej obsługi zestawu kołowego 
$\Rightarrow$ niewłaściwie przeprowadzonym procesem rolowania powierzchniowego, w wyniku którego ukrywa się wady powierzchniowe w osi

$\Rightarrow$ niewłaściwie przeprowadzonym procesem technologicznym wytwarzania osi, w wyniku którego powstaja naprężenia rozciagające na powierzchni osi o wartościach znacznie przekraczających wartości dopuszczalne, wymienione w p. PN-EN 13261+A1:2011 [15]

$\Rightarrow$ nadzwyczajne obciążenia osi, znaczenie przekraczające te które są wymienione w PN-EN 13103+A1:2011 [12] oraz PN-EN 13104+ A1:2011 [13], pojawiające się cyklicznie.

Traktując ogólnie oś zestawu kołowego, przyczyny pęknięć zmęczeniowych mogą pojawić się:

- na etapie wytwarzania (niewłaściwie przeprowadzony proces kucia, obróbki cieplnej, obróbki mechanicznej oraz rolowania powierzchniowego lub innych zabiegów wzmacniających)

- podczas niewłaściwej eksploatacji

- podczas napraw i przeglądów pojazdów szynowych, podczas których może być dokonana niewłaściwa kwalifikacja osi do dalszej eksploatacji komercyjnej.

Pęknięcia zmęczeniowe pojawiają się w różnym wieku osi, co oznaczałoby że wiek osi nie ma wpływu na bezpieczną eksploatację, o ile jest ona prawidłowo utrzymana. Pozytywny wynik badań stanowiskowych przeprowadzonych na próbkach osi w zakresie do $10^{7}$ cykli obciążeń nie gwarantują jeszcze, że pęknięcia zmęczeniowe nie wystapią w eksploatacji. Jak wykazano we wcześniejszych opracowaniach w pojazdach trakcyjnych osie zestawów kołowych posiadają bardzo duże przebiegi i pracują $\mathrm{w}$ zakresie giga-cyklowym obciążeń zmęczeniowych tzn. $2 \times 10^{9}$ cykli obciążeń zmęczeniowych. Ilość cykli obciążeń w zależności od przebiegu kilometrowego pojazdu z kołami o średnicach $\phi 920 \mathrm{~mm}$ oraz $\phi 1000 \mathrm{~mm}$ jest przedstawiona $\mathrm{w}$ tabeli 1. Niniejsze zestawienie zostało wykonane $w$ oparciu o założenie, że pełny cykl zmęczeniowy odpowiada jednemu obrotowi koła, natomiast obrót koła odpowiada drodze pojazdu odpowiadającej pełnemu obwodowi koła, liczonemu na bazie średnicy tocznej koła. Zdecydowana większość uszkodzeń w trakcie eksploatacji ma charakter przełomów zmęczeniowych.

Przelomy zmęczeniowe pojawiają się $w$ różnych sektorach osi w różnym wieku osi zestawu kołowego. Spostrzeżenie to, oparte na faktach zebranych $\mathrm{z}$ eksploatacji komercyjnej jest kluczowe do wyciagania następnych wniosków. Wychodząc $\mathrm{z}$ założenia, że pomimo odpowiednio wysokiej granicy zmęczenia (wynoszącej dla pełnej osi zestawu kołowego EA1N 200MPa) i zapewnieniu współczynników bezpieczeństwa, wymaganych przez PN-EN 13103+A1:2011 [12] oraz PN-EN 13104:2011+A1 [13] nie można rezygnować $\mathrm{z}$ dodatkowych zabiegów technologicznych, zwiększających wytrzymałość zmęczeniową, do których można zaliczyć między innymi rolowanie powierzchni (wałeczkowanie). Przekonania o braku odpowiedniego oprzyrządowania nie są do końca przekonywujące, zwłaszcza że maszyny do rolowania osi można nabyć w firmie Hegenscheidt- MFD GmbH \&Co.KG w Erkelenz. Istotną cechą innowacyjną nowej maszyny jest pełna automatyka procesu w wyniku sterowania procesem rolowania za pośrednictwem komputera. Maszyna do automatycznego wałeczkowania osi zestawów kołowych jest przedstawiona na fotografii, zamieszczonej na rys. 1 .

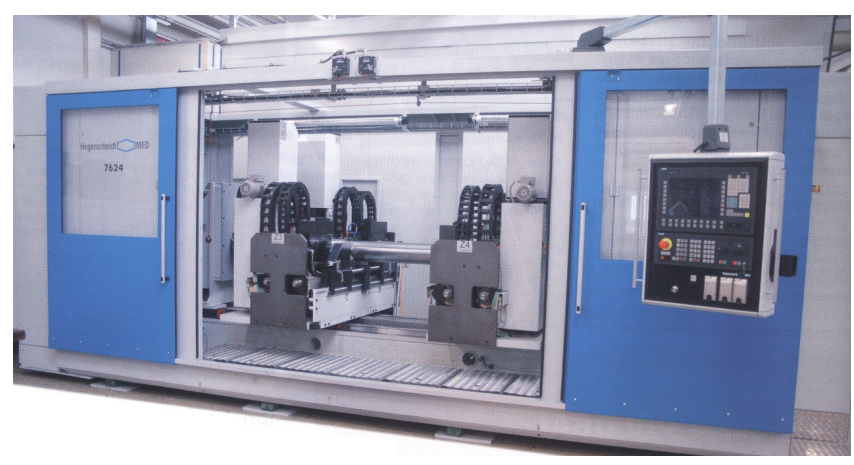

Rys.1. Maszyna do automatycznego wałeczkowania osi zestawów kołowych firmy Hegenscheidt- MFD GmbH \&Co.KG w Erkelenz wg [1]

Urządzenie jest maszyną wyposażoną $\mathrm{w}$ dwa niezależne suporty, które posiadają trzy pary rolek dogniatających oraz wygładzających.

Oczywiście możliwe jest stosowanie innych zabiegów technologicznych, zwiększających wytrzymałość zmęczeniowa, które są wymienione w opracowaniu [5]. Ww. metoda opisana w [1] potwierdza słuszność wałeczkowania, której metodyka jest przedstawiona $\mathrm{w}$ instrukcji OW-1166/1 [33] a jej skuteczność potwierdzona wytrzymałościowymi badaniami stanowiskowymi przeprowadzonymi w IPS „Tabor” [8]. Dodatkowe czynniki technologiczne, gwarantujące większą granicę zmęczenia dla materiału osi, a tym samym większe naprężenia dopuszczalne, zapewniają:

- większą żywotność osi zestawu kołowego

- większą odporność osi na nadzwyczajne czynniki pojawiające się w eksploatacji, jak np. nadzwyczajne obciążenia o charakterze udarowym, lub obciążenia zmęczeniowe o większej amplitudzie pojawiające się okresowo

- zachowanie geometrii osi w stanie wyjściowym, osiagniętej u producenta przez większość lub cały okres eksploatacji

- tworzenie pewnego zapasu bezpieczeństwa, związanego z nieprawidłową kwalifikacją osi podczas przeglądów, napraw okresowych oraz głównych.

Skuteczność czynników technologicznych przed wprowadzeniem osi do eksploatacji komercyjnej 
powinna być potwierdzona badaniami stanowiskowymi na próbkach w skali 1:1 przez certyfikowaną jednostkę badawczą. Bezpieczeństwo osi zestawu kołowego w zakresie wytrzymałości zmęczeniowej zależy nie tylko od czynników ww. wymienionych, ale również od prawidłowego montażu oraz stanu technicznego elementów montowanych na osi do jakich należą:

- koła monoblokowe lub koła obręczowane

- tarcze hamulcowe

- koła zębate napędu

- maźnice wraz z łożyskami.

\subsection{Analiza przełomu zmęczeniowego}

Jak wykazuje praktyka eksploatacyjna osie pękają podczas eksploatacji w różnych przekrojach, co świadczyłoby raczej o braku jednolitej przyczyny uszkodzeń osi w eksploatacji. Oś nie jest przecież belką o równomiernej wytrzymałości. Pęknięcia najczęściej mają charakter zmęczeniowy. Przykład takiego przełomu zmęczeniowego jest przedstawiony na fotografii, zamieszczonej na rys.1.Pęknięcie to wystąpiło na przedpiaściu osi, która została wyprodukowana 25 lat temu.

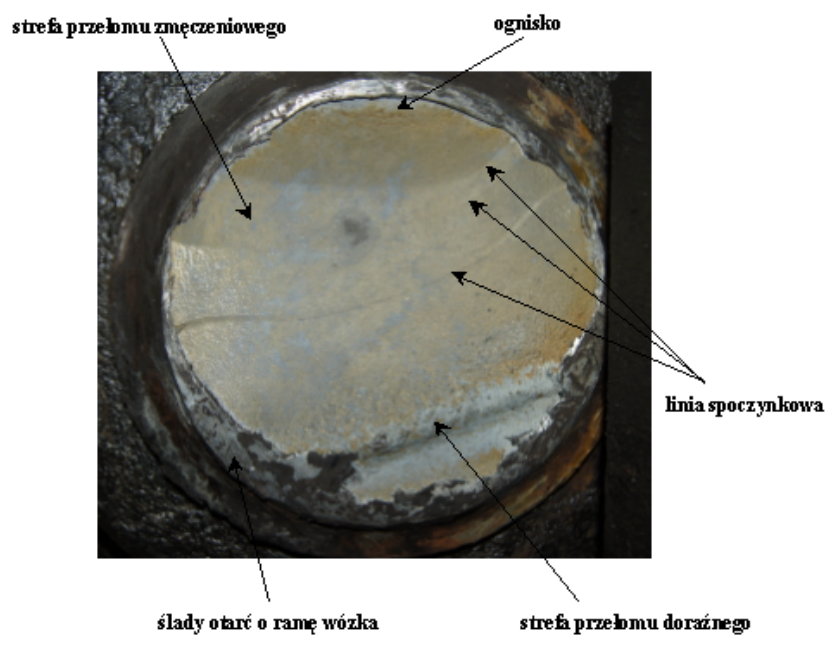

Rys.2. Przykładowy przełom zmęczeniowy w osi zestawu kołowego z czopem $120 \times 179 \mathrm{~mm}$

Pozostałe wymiary osi zgodne z normą PN-92/K91048 [24] oraz z kartą UIC 510-1 [26]. Jak widać z fotografii na rys.2. przekrój zmęczeniowy dzieli się na dwie strefy. Pierwsza strefa charakteryzuje się gładką powierzchnia, natomiast druga ma charakter złomu doraźnego. $\mathrm{W}$ podanym przykładzie przełomu zmęczeniowego zdecydowanie większy udział zajmuje przekrój o powierzchni gładkiej o charakterze drobnoziarnistym. Powierzchnia ta jest tym bardziej gładka im niższe działały naprężenia zmęczeniowe a więc im dłuższy był czas rozwijania pęknięcia. Gładkość powierzchni jest spowodowana wzajemnym tarciem ( kontaktowaniem się) powierzchni lub z udziałem wyrwanych cząstek materiału. W strefie zmęczeniowej daje się zauważyć ślady przesuwania się czoła pęknięcia pod postacią mniej lub bardziej wyraźnie zaznaczonych linii. Linie te, których powstanie nie wydaje się być dotychczas dostatecznie wyjaśnione, spotyka się pod nazwą linii zmęczeniowych, spoczynkowych, umocnienia, strefowych lub warstwowych (niem. Rastlinien, Bruchlinien, ang. lines of arrest, beach markings).

Powstanie tych linii przypisywano:

- odkształceniom plastycznym występującym na czole pęknięcia, wynikającym z krótkotrwałych przeciążeń

- zmianie kierunku obciążenia

- zmianie wartości obciążenia

- pokonaniu obszarów o różnych własnościach

- przerwom w obciążeniu.

Linie zmęczeniowe są definiowane jako makroskopowe symptomy złomu zmęczeniowego. Można postawić hipotezę, ze linie zmęczeniowe są wywoływane najprawdopodobniej zatrzymaniem lub zmniejszeniem rozwoju pęknięcia z różnych przyczyn zewnętrznych i wewnętrznych. W liniach mogą znaleźć swoje odbicie te wartości amplitudy naprężenia które nie przyczyniają się do chwilowego wzrostu pęknięcia po okresach działania wyższych. Można w tym przypadku postawić tezę o wzroście umocnienia $\mathrm{w}$ miejscach linii. Brak linii zmęczeniowych może świadczyć o ustalonej i ciaggłej pracy elementów przy niezmiennej amplitudzie. Regularny układ linii sygnalizuje o regularnych, okresowo zmiennych warunkach obciążenia. Nieregularne odstępy między liniami mogą być spowodowane różnie powtarzającymi się zmianami obciążenia $\mathrm{w}$ czasie pracy układu. Coraz silniejsze osłabienie przez postępujące pęknięcie prowadzi na ogół gwałtownej „dekohezji”. Tę strefę zniszczoną, końcową część przełomu nazywa się złomem lub strefą resztkową (final rupture surface, Restbruchfläche). Strefa ta podobna jest do złomu wywołanego jednorazowym przerwaniem, co wcale nie oznacza, że nastapiło ono w czasie jednego cyklu obciążenia. Ze stosunku powierzchni zmęczeniowej do resztkowej można wnioskować orientacyjnie o współczynniku bezpieczeństwa . Im stosunek jest mniejszy tym, tym niższy wybrano współczynnik bezpieczeństwa i tym większe było przeciążenie.

Podany wyżej przykład pęknięcia osi zestawu kołowego jest $\mathrm{z}$ pewnością wynikiem splotu kilku niekorzystnych czynników, które pojawiły się w eksploatacji:

- zarysowanie powierzchniowe oraz uszkodzenia mechaniczne pojawiające się w trakcie napraw i przeglądów okresowych, spowodowane przypadkowymi (niezamierzonymi) uderzeniami, które w pewnym momencie eksploatacji przerodziło się w pęknięcie zmęczeniowe; przykład takiego zarysowania powierzchni 
spowodowanego przypadkowym uszkodzeniem podczas użycia przyrządu mechanicznego do ściagania pierścieni łożysk oraz pierścienia oporowego. Przykład taki jest przedstawiony na rys.3. W związku $\mathrm{z}$ powyższym zaleca się stosowanie urządzenia indukcyjnego do ściagania pierścieni wewnętrznych łożysk.

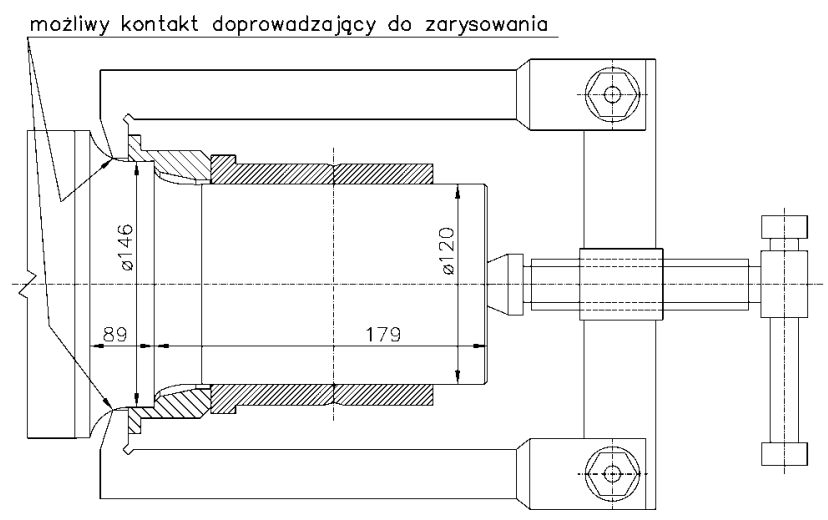

Rys.4. Mechaniczny ściagacz do łożysk tocznych i potencjalna możliwość uszkodzenia podpiaścia osi

- korozja atmosferyczna, wywołana takimi czynnikami jak klimat wilgotny, klimat morski, atmosfera przemysłowa, woda, roztwory soli; jak okazuje się z praktyki tlen atmosferyczny zmniejsza wytrzymałość zmęczeniową, dlatego też doświadczenia badawcze przeprowadzone w próżni wykazały większą wytrzymałość zmęczeniową, aniżeli niż w powietrzu atmosferycznym [8]; przykład spadku wytrzymałości zmęczeniowej w zależności od zawartości soli w powietrzu atmosferycznej jest przedstawiony na wykresie, zamieszczonym na rys.5.

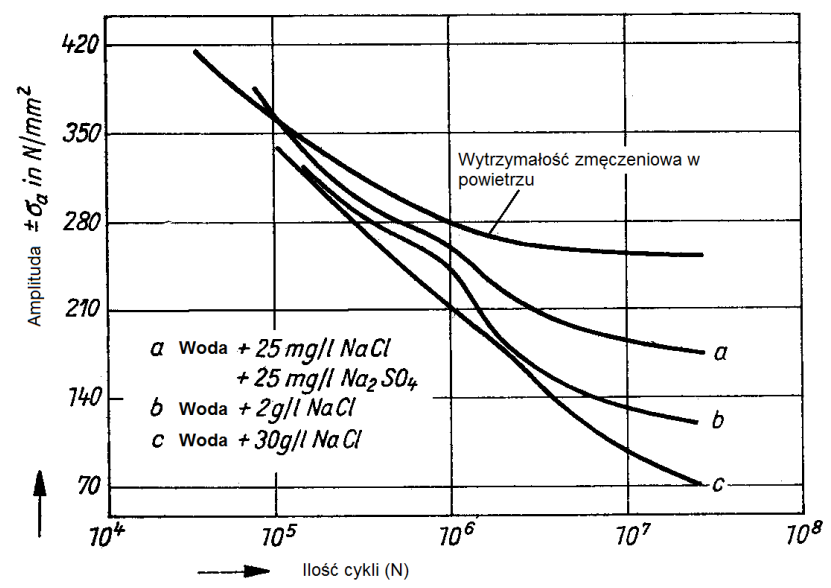

Rys.5. Spadek wytrzymałości zmęczeniowej przy zginaniu obrotowym próbki ze stali o zawartości $0,42 \%$ węla i wytrzymałości na rozciagganie $\mathrm{R}_{\mathrm{m}}=680 \mathrm{MPa}$ w zależności od zawartości soli w wodzie [9]
- niewłaściwe zabezpieczenie antykorozyjne, niespełniające wymagań dotyczących powłok malarskich dla osi zestawów kołowych, które są przedstawione w PN-EN 13261+A1:2011 [15].

- działanie okresowo większych sił niż zakładano $\mathrm{W}$ metodyce obliczeń osi PN-EN 13103+A1:2011 [12]. Działanie okresowo zmiennych sił może być wywołane płaskim miejscem na kole.

Wpływ poszczególnych mediów na granicę zmęczenia dla stali C45 w stanie normalizowanym na granicę zmęczenia jest przedstawiony w tabeli 1 .

Wpływ różnych mediów na wytrzymałość zmęczeniową stali C45 ( w stanie normalizowanym) na granice zmęczenia przy obustronnym zginaniu. Tabela 1

\begin{tabular}{|c|c|c|c|}
\hline L.p. & Medium & $\begin{array}{c}\text { Granica zmę- } \\
\text { czenia } \\
{[\mathbf{M P a}]}\end{array}$ & {$[$ [\%] } \\
\hline 1. & Powietrze & 255 & 100 \\
\hline 2. & Roztwór $\mathrm{NaCl} \mathrm{0,004 \%}$ & 147 & 58 \\
\hline 3. & Roztwór $\mathrm{NaCl}$ 3\% & 100 & 39 \\
\hline 4. & $\begin{array}{c}\text { Roztwór NaCl, nasą- } \\
\text { czony } \mathrm{H}_{2} \mathrm{~S}\end{array}$ & 92 & 28 \\
\hline 5. & $\begin{array}{c}\text { Roztwór z 0,5n Cl; } \mathrm{n} \\
\mathrm{Na}_{2} \mathrm{Co}_{3}, 0,8 \mathrm{n} \mathrm{NaHCO}\end{array}$ & 200 & 78 \\
\hline
\end{tabular}

\subsection{Ukręcenia czopa osi zestawu kołowego}

Omawiane pęknięcie zmęczeniowe pojawiło się na przedpiaściu osi, a przyczyna była ściśle związana ze stanem osi zestawu kołowego. Inny przypadek pęknięcia osi jest przedstawiony na rys. 6 .

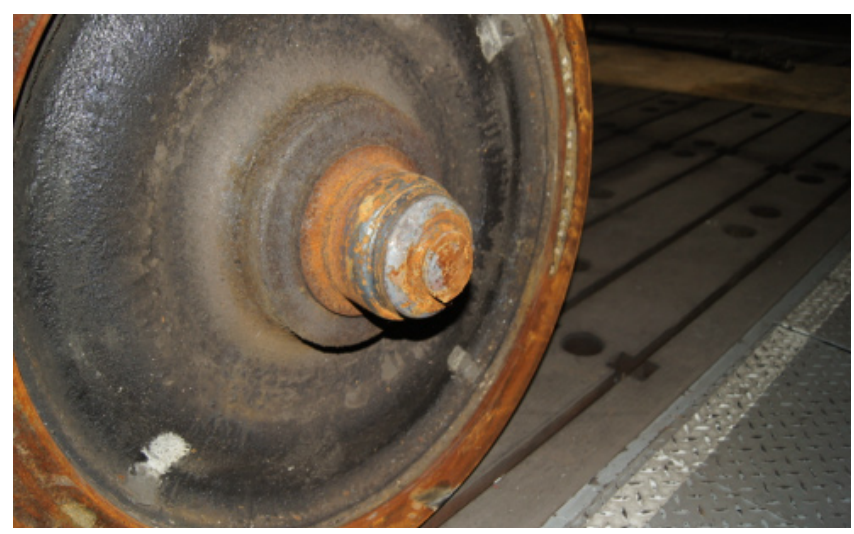

Rys.6. Ukręcony czop osi zestawu kołowego wagonu towarowego

Przypadek ten pojawia się relatywnie często wśród analizowanych wypadków uszkodzenia osi zestawu kołowego. Przypadek ten jest wynikiem złej współpracy czopa $z$ łożyskami NJ+NJP $120 \times 240 \times 80 \mathrm{~mm}$. Nieprawidłowa współpraca czopa $\mathrm{z}$ łożyskami może pojawić się w wyniku:

- braku smaru lub niewłaściwie dobranego gatunku smaru; zwraca się uwagę na fakt że smary łożyskowe powinny przejść pełną homologację wg karty UIC 814 [31]; stan techniczny uszczelnień powinien uniemożliwiać wypływ smaru oraz wnikanie zanieczyszczeń zmieniających własności smaru 
- nieprawidłowego montażu łożysk, wskutek czego luzy promieniowe lub poosiowe są zbyt małe

- pęknięć zmęczeniowych elementów łożysk, jak pierścienie wewnętrzne, wałeczki lub pierścienie zewnętrzne.

Bardzo niebezpieczne jest pęknięcie pierścieni wewnętrznych, które prowadzi do ich poluzowania, a następnie zejścia maźnicy z czopa. Rysunek czopa po zejściu z niego maźnicy przedstawiono na rys.7. Maźnica, która spadła z osi, jest przedstawiona na rys.8. Przypadek ten przeanalizowano dokładniej, wspomagając się obliczeniami wytrzymałościowymi.

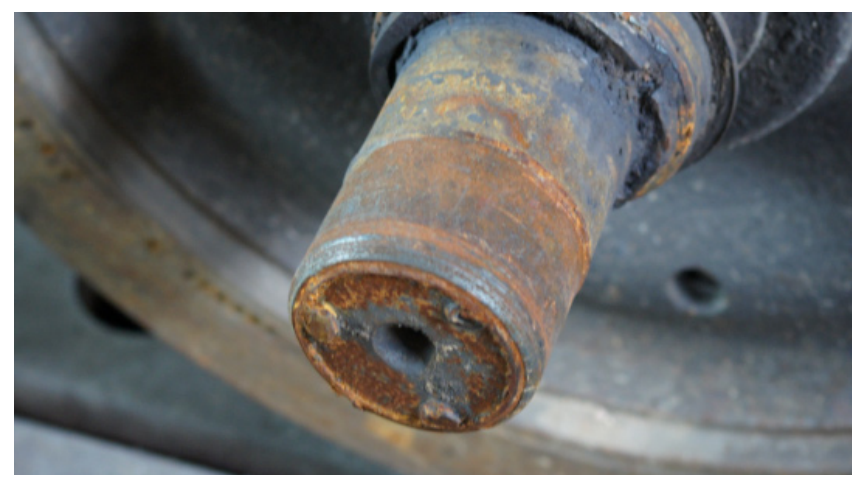

Rys.7. Czop osi zestawu kołowego o wymiarach $120 \times 179$ mm, z którego spadła maźnica

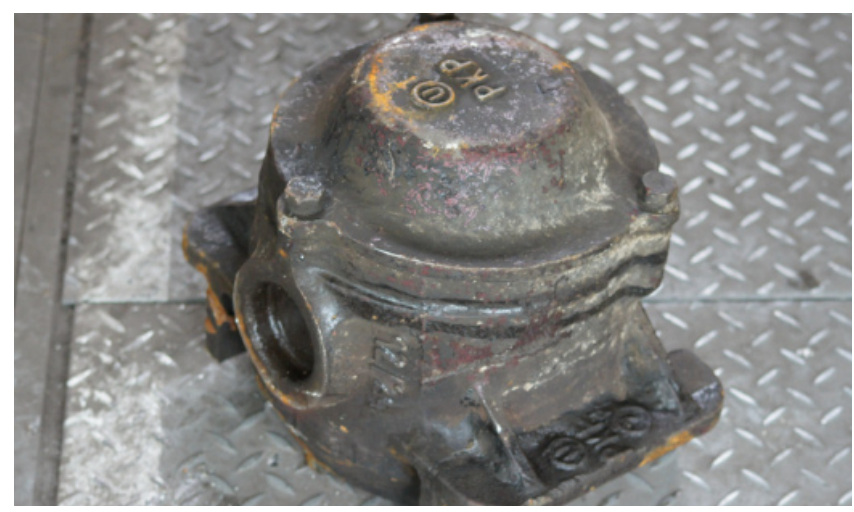

Rys.8. Maźnica, która spadła z czopa osi zestawu kołowego

Jeśli przyjąć, że średnica czopa osi w stanie nowym wynosi $\varnothing 120 \mathrm{p} 6 \mathrm{~mm}\left(\varnothing 120_{+0,037}^{+0,059} \mathrm{~mm}\right)$ natomiast pomierzone średnice nie wskazują na zastosowanie tożysk naprawczych wówczas należy wyjść z założenia, że zmniejszone średnice na czopie osi świadczą o wytarciu materiału czopa osi przez obydwa pierścienie wewnętrzne łożysk tocznych. Ww. zjawisko można wytłumaczyć tym, że istnieje bardzo duża różnica twardości pomiędzy materiałem użytym na pierścienie łożysk. Twardość czopa osi, wykonanej z materiału P35N wg PN-84/H-84027/03 [22] w stanie normalizowanym po operacji rolowania powierzchniowego wg instrukcji OW-1166/1 [33] wynosi co najwyżej $240 \mathrm{HB}$ (ok. 22,5 HRC wg PN-93/H-04357 [25]), natomiast pierścieni wewnętrznych łożysk $59 \div 84$ HRC (stal ŁH15SG wg PN-74/H-84041 [21]).
W przejściu między obydwoma wytartymi strefami znajduje się „wypływka” materiału czopa osi. Wypływka nie ma regularnej średnicy i powstała w strefie przejściowej pomiędzy mocowaniem obydwu pierścieni wewnętrznych. Niniejsze zjawisko świadczyłoby o poluzowaniu się pierścieni wewnętrznych łożysk w stosunku do czopa osi. Należy nadmienić, że wciski przy średnicy pierścienia wewnętrznego $120_{-0,015} \mathrm{~mm}$ oraz średnicy czopa $120_{+0,037}^{+0,059} \mathrm{~mm}$ wynoszą odpowiednio:

$$
\mathrm{W}_{\min }=120_{+0,037}-120=0,037 \mathrm{~mm}
$$

oraz

$$
\mathrm{W}_{\max }=120^{+0,059}-120_{-0,015}=0,074 \mathrm{~mm}
$$

Przy obliczeniach pominięto udział chropowatości czopa osi oraz powierzchni wewnętrznej pierścieni wewnętrznych na wielkość wcisku:

$>$ wpływ wcisku; przy obliczeniach należy pamiętać, że efektywny wcisk jako różnica pomiędzy średnicami czopa oraz pierścienia wewnętrznego jest pomniejszony o udział chropowatości wg następującej zależności:

$$
\mathrm{w}^{\prime}=\mathrm{w}_{\mathrm{NOM}}-2 \varphi \cdot\left(\mathrm{R}_{\mathrm{z} 1}+\mathrm{R}_{\mathrm{z} 2}\right)
$$

gdzie:

$$
\text { w' - wcisk rzeczywisty }
$$

$\mathrm{w}_{\text {NOM }}$ - wcisk nominalny (różnica pomiędzy średnicą czopa osi i pierścienia wewnętrznego łożyska)

$\varphi$ - współczynnik zgniecenia nierówności, wynoszący $w$ zakresie $\varphi=0,5 \div 0,6$ (przyjmowany wg literatury)

$\mathrm{R}_{\mathrm{z} 1}, \mathrm{R}_{\mathrm{z} 2}$ - wysokość nierówności wtłaczanych powierzchni tzn. otworu pierścienia wewnętrznego łożyska oraz czopa osi.

Stopień zgniecenia nierówności zależy od wielkości wcisku, wysokości, kształtu i gęstości rozmieszczenia nierówności, twardości i wytrzymałości elementów, obejmującego i obejmowanego. Rzeczywisty stopień zgniecenia nierówności, ustalający się po pewnym czasie użytkowania, który określa eksploatacyjna nośność połączenia, zależy od wielkości i rodzaju obciążenia działającego na połączenie oraz od liczby przeprowadzonych operacji demontażu-montażu połączenia. Rzeczywista wysokość nierówności po każdym demontażu i ponownym montażu ulega zmniejszeniu i ustala się na określonym poziomie po trzech-czterech demontażach.

Reasumując, na rzeczywistą wartość siły przy wtłaczaniu ma wpływ wiele czynników, które mają charakter stochastyczny. Należy zwrócić szczególną uwagę na to, że siła wtłaczania jest wprost proporcjonalna do dwóch czynników tzn. nacisku powierzchniowego (wcisku) oraz współczynnika tarcia. Współczynnik 
tarcia z kolei maleje ze wzrostem nacisku powierzchniowego.

Zakładając, że pierścienie wewnętrzne łożysk były montowane przez wtłaczanie na zimno, naciski powierzchniowe pomiędzy czopem osi oraz pierścieniem wewnętrznym wyznaczono ze wzoru:

gdzie:

$$
\mathrm{p}=\frac{\mathrm{W}}{\mathrm{A} \cdot 1 \cdot \mathrm{d}_{0}}
$$

w - wcisk jako różnica średnic czopa osi zestawu

kołowego i pierścieni wewnętrznego łożyska

A - współczynnik

$\mathrm{d}_{0}$ - średnica czopa osi zestawu kołowego.

Współczynnik A można wyznaczyć ze wzoru:

oraz:

$$
A=\frac{1}{C_{0}}+\frac{1}{C_{P}}
$$

$$
\begin{gathered}
\mathrm{C}_{0}=\frac{\mathrm{E} \cdot 1}{1-v} \\
\mathrm{C}_{\mathrm{P}}=\frac{\mathrm{El}}{\frac{\mathrm{d}_{\mathrm{P}}^{2}+\mathrm{d}_{0}^{2}}{\mathrm{~d}_{\mathrm{P}}^{2}-\mathrm{d}_{0}^{2}}+v}
\end{gathered}
$$

gdzie:

E - moduł Younga (moduł sprężystości stali w kierunku wzdłużnym)

$\mu$ - współczynnik Poissona

$\mathrm{d}_{\mathrm{P}}$ - średnica zewnętrzna pierścienia wewnętrznego łożyska.

Przyjmując na podstawie dokumentacji konstrukcyjnej $\mathrm{d}_{\mathrm{p}}=150 \mathrm{~mm}$ oraz $\mathrm{d}_{0}=120 \mathrm{~mm}$ otrzymuje się:

$$
\frac{\mathrm{d}_{\mathrm{P}}^{2}+\mathrm{d}_{0}^{2}}{\mathrm{~d}_{\mathrm{P}}^{2}-\mathrm{d}_{0}^{2}}=\frac{0,150^{2}+0,120^{2}}{0,150^{2}-0,120^{2}}=4,5555 .
$$

Podstawiając $E=2,06 \cdot 10^{11} \mathrm{~N} / \mathrm{mm}^{2}$ oraz $\mathrm{l}=0,08+0,064=$ $0,144 \mathrm{~m}$ i $\nu=0,3$ do wzoru (6) otrzymuje się:

$$
\mathrm{C}_{0}=\frac{2,06 \cdot 10^{11} \cdot 0,144}{1-0,3}=4,2377 \cdot 10^{10} \mathrm{~N} / \mathrm{m}
$$

Podstawiając $\quad E=2,06 \cdot 10^{11} \quad \mathrm{~N} / \mathrm{mm}^{2}, \quad 1=0,08+0,064=$ $0,144 \mathrm{~m}, \mathrm{v}=0,3$ oraz wartość współczynnika 4,5555 do wzoru (7) otrzymuje się:

$$
\mathrm{C}_{\mathrm{P}}=\frac{2,06 \cdot 10^{11} \cdot 0,144}{4,5555+0,3}=6,1093 \cdot 10^{9} \mathrm{~N} / \mathrm{m}
$$

Wartość współczynnika „A” wynosi:

$$
\mathrm{A}=\frac{1}{4,2377 \cdot 10^{10}}+\frac{1}{0,61093 \cdot 10^{10}}=1,8728 \cdot 10^{-10} \mathrm{~m} / \mathrm{N}
$$

Wartość minimalnych nacisków powierzchniowych $\mathrm{p}_{\mathrm{MIN}}$ na powierzchni osadczej czopa wynosi:

$$
\mathrm{p}_{\text {MIN }}=\frac{0,037 \cdot 10^{-3}}{1,8728 \cdot 0,144 \cdot 0,120} \cdot 10^{10}=11,43 \mathrm{MPa}
$$

Wartość maksymalnych nacisków powierzchniowych $\mathrm{p}_{\mathrm{MAX}}$ na powierzchni osadczej czopa wynosi:

$$
\mathrm{p}_{\text {MAX }}=\frac{0,074 \cdot 10^{-3}}{1,8728 \cdot 0,144 \cdot 0,120} \cdot 10^{10}=22,86 \mathrm{MPa}
$$

Obliczeniowe siły wtłaczania można wyznaczyć ze wzoru:

$$
\mathrm{F}=\mu \cdot \pi \cdot \mathrm{d}_{0} \cdot 1 \cdot \mathrm{p}
$$

gdzie:

$$
\begin{aligned}
& \mu \text { - współczynnik tarcia } \\
& \mathrm{d}_{0} \text {-średnica osadzenia } \\
& 1 \text { - długość połączenia (obydwu pierścieni) } \\
& \text { p - nacisk powierzchniowy. }
\end{aligned}
$$

Po wstawieniu $\mu=0,08$ (min. współczynnik tarcia przy wtłaczaniu), $\mathrm{d}_{0}=0,120 \mathrm{~m}, \mathrm{l}=0,144 \mathrm{~m}, \mathrm{p}_{\mathrm{MIN}}=11,43 \mathrm{MPa}$ do wzoru (14) otrzymuje się:

$$
\mathrm{F}_{1}=0,08 \cdot \pi \cdot 144 \cdot 120 \cdot 11,43=49639 \mathrm{~N}=49 \mathrm{kN}
$$

Po wstawieniu $\mu=0,12$ (max. współczynnik tarcia przy wtłaczaniu), $\mathrm{d}_{0}=0,120 \mathrm{~m}, \mathrm{l}=0,144 \mathrm{~m}, \mathrm{p}_{\mathrm{MIN}}=11,43 \mathrm{MPa}$ do wzoru (14) otrzymuje się:

$$
\mathrm{F}_{2}=0,12 \cdot \pi \cdot 144 \cdot 120 \cdot 11,43=74459 \mathrm{~N}=74 \mathrm{kN}
$$

Po wstawieniu $\mu=0,08$ (min. współczynnik tarcia przy wtłaczaniu), $\mathrm{d}_{0}=0,120 \mathrm{~m}, \mathrm{l}=0,144 \mathrm{~m}, \mathrm{p}_{\mathrm{MAX}}=22,86 \mathrm{MPa}$ do wzoru (14) otrzymuje się:

$$
\mathrm{F}_{3}=0,08 \cdot \pi \cdot 144 \cdot 120 \cdot 22,86=99279 \mathrm{~N}=99 \mathrm{kN}
$$

Po wstawieniu $\mu=0,12$ (max. współczynnik tarcia przy wtłaczaniu), $\mathrm{d}_{0}=0,120 \mathrm{~m}, \mathrm{l}=0,144 \mathrm{~m}, \mathrm{p}_{\mathrm{MAX}}=22,86 \mathrm{MPa}$ do wzoru (14) otrzymuje się:

$\mathrm{F}_{4}=0,12 \cdot \pi \cdot 144 \cdot 120 \cdot ? 22,86 \mathrm{MPa}=148919 \mathrm{kN}=148 \mathrm{kN}$ (18)

Po wstawieniu $\mu_{\text {sr }}=0,10$ (średni współczynnik tarcia przy wtłaczaniu), $\mathrm{d}_{0}=0,120 \mathrm{~m}, \mathrm{l}=0,144 \mathrm{~m}, \mathrm{p}_{\text {MIN }}=11,43$ MPa do wzoru (14) otrzymuje się:

$$
\mathrm{F}_{5}=0,10 \cdot \pi \cdot 144 \cdot 120 \cdot 11,43=62049 \mathrm{~N}=62 \mathrm{kN}
$$

Po wstawieniu $\mu_{\mathrm{sr}}=0,10$ (średni współczynnik tarcia przy wtłaczaniu), $\mathrm{d}_{0}=0,120 \mathrm{~m}, \mathrm{l}=0,144 \mathrm{~m}, \mathrm{p}_{\mathrm{MAX}}=22,86$ MPa do wzoru (14) otrzymuje się:

$$
\mathrm{F}_{6}=0,10 \cdot \pi \cdot 144 \cdot 120 \cdot 22,86=124099 \mathrm{~N}=124 \mathrm{kN}
$$

Zestawienie sił wtłaczania dla obydwu pierścieni wewnętrznych łożyska jest przedstawione w tabeli 2 .

Moment obrotowy jaki jest w stanie przenieść połączenie wtłaczane pierścieni wewnętrznych łożysk można wyznaczyć ze wzoru:

$$
\mathrm{M}_{\mathrm{OP}}=0,5 \cdot \mathrm{F} \cdot \mathrm{d}_{0}
$$

Zestawienie momentów przenoszonych przez połączenia wtłaczane pierścieni wewnętrznych łożysk jest przedstawione $\mathrm{w}$ tabeli 3 . 
Zestawienie sil wtlaczania dla pierścieni wewnętrznych lożysk NJ+NJP w zależności od współczynnika tarcia i od wartości nacisków powierzchniowych

Tabela 2

\begin{tabular}{|c|c|c|c|c|c|}
\hline L.p. & $\begin{array}{c}\text { Wartość współczynnika } \\
\text { tarcia } \\
{[-]}\end{array}$ & $\begin{array}{c}\text { Wartość nacisków po- } \\
\text { wierzchniowych } \\
{[\mathbf{M P a}]}\end{array}$ & $\begin{array}{c}\text { Wartość sil wtlacza- } \\
\text { nia } \\
{[\mathbf{k N}]}\end{array}$ & $\begin{array}{c}\text { Udzial sily } \\
\text { wtlaczania dla } \\
\text { lożyska NJP }\end{array}$ & $\begin{array}{c}\text { Udzial sily } \\
\text { wtlaczania dla } \\
\text { lożyska NJ }\end{array}$ \\
\hline 1. & 0,08 & 11,43 & 49 & 21,77 & 27,22 \\
\hline 2. & 0,12 & 22,86 & 74 & 32,88 & 41,11 \\
\hline 3. & 0,08 & 11,43 & 99 & 44 & 55 \\
\hline 4. & 0,12 & 22,86 & 148 & 65,77 & 82,22 \\
\hline 5. & 0,10 & 11,43 & 62 & 27,55 & 34,44 \\
\hline 6. & 0,10 & 22,86 & 124 & 55,11 & 68,89 \\
\hline
\end{tabular}

Zestawienie momentów sił wtlaczania dla układu pierścień wewnętrzny-czop zestawu kołowego w zależności od wspólczynnika tarcia i od wartości nacisków powierzchniowych na powierzchni osadczej Tabela 3

\begin{tabular}{|c|c|c|c|c|c|c|c|}
\hline L.p. & $\begin{array}{c}\text { Wartość wspól- } \\
\text { czynnika tarcia } \\
{[-]}\end{array}$ & $\begin{array}{c}\text { Wartość sil } \\
\text { wtlaczania } \\
{[\mathbf{k N ]}}\end{array}$ & $\begin{array}{c}\text { Udzial sily } \\
\text { wtlaczania } \\
\text { dla lożyska } \\
\text { NJP }\end{array}$ & $\begin{array}{c}\text { Wartość mo- } \\
\text { Udzial sily } \\
\text { wentuczania } \\
\text { dla lożyska } \\
\text { NJ } \\
\text { wego, który } \\
\text { jest w stanie } \\
\text { przenieść pier- } \\
\text { ścień we- } \\
\text { wnętrzny lo- } \\
\text { żysk NJ+NJP } \\
\text { [kNm] }\end{array}$ & $\begin{array}{c}\text { Wartość mo- } \\
\text { mentu obroto- } \\
\text { wego, który } \\
\text { jest w stanie } \\
\text { przenieść pier- } \\
\text { ścień lożyska } \\
\text { NJP } \\
\text { [kNm] }\end{array}$ & $\begin{array}{c}\text { Wartość mo- } \\
\text { mentu obroto- } \\
\text { wego, który } \\
\text { jest w stanie } \\
\text { przenieść pier- } \\
\text { ścień lożyska } \\
\text { NJ } \\
{[\mathbf{k N m}]}\end{array}$ \\
\hline 1. & 0,08 & 49 & 21,77 & 27,22 & 3,67 & 1,63 & 2,04 \\
\hline 2. & 0,12 & 74 & 32,88 & 41,11 & 5,55 & 2,46 & 3,08 \\
\hline 3. & 0,08 & 99 & 44 & 55 & 7,42 & 3,3 & 4,12 \\
\hline 4. & 0,12 & 148 & 65,77 & 82,22 & 11,1 & 4,93 & 6,16 \\
\hline 5. & 0,10 & 62 & 27,55 & 34,44 & 4,65 & 2,06 & 2,58 \\
\hline 6. & 0,10 & 124 & 55,11 & 68,89 & 9,3 & 4,13 & 5,16 \\
\hline
\end{tabular}

W przypadku poluzowania pierścieni wewnętrznych łożysk NJ+NJP 120×240×80 mm można wnioskować, że łożysko nie mogło się obracać. Wówczas poluzowanie to wynikało $\mathrm{z}$ oddziaływania momentu obrotowego, jaki przenosi zestaw kołowy. Moment tarcia jaki przenosi zestaw kołowy w stanie ładownym wynosi odpowiednio:

$$
\mathrm{M}_{\mathrm{K}}=0,5 \mu \cdot 2 \mathrm{Q}_{0} \cdot 0,5 \mathrm{D}_{0}
$$

gdzie:

$\mu$ - współczynnik tarcia pomiędzy kołem a szyna, wynoszący 0,35 ;

$\mathrm{Q}_{0}$ - statyczny nacisk pionowy jednego koła na szynę;

$2 \mathrm{Q}_{0}$ - statyczny nacisk pionowy zestawów kołowych na szyny,

$2 \mathrm{Q}_{0}=200 \mathrm{kN}$ w stanie maksymalnie załadowanym (masa brutto wagonu $80000 \mathrm{~kg}$ )

$\mathrm{D}_{0}$ - średnica toczna zestawu kołowego; do obliczeń przyjęto średnią wartość $0,920 \mathrm{~m}$
Po wstawieniu danych liczbowych do wzoru (22) tzn. $\mu=0,35,2 Q_{0}=200 \mathrm{kN}$ oraz $\mathrm{D}=0,920$ otrzymuje się:

$$
\mathrm{M}_{\mathrm{K}}=0,5 \cdot 0,36 \cdot 200 \cdot 0,920=33,12 \mathrm{Nm}
$$

Jak widać $\mathrm{z}$ wykonanych obliczeń moment $\mathrm{M}_{\mathrm{K}}$ (w przypadku jednego koła stanowi połowę ww. wartości) jest znacznie większy od wyliczonych wartości w tabeli 3. W ten sposób przy zablokowaniu zdolności obrotowej lożyska musiało dojść do poluzowania pierścieni wewnętrznych $\mathbf{N J}+\mathbf{N J P}$. Zjawisko poluzowania pierścieni wewnętrznych wystapi nawet wtedy jeśli uwzględnić, że momenty obrotowe sił tarcia są większe o $20 \div 30 \%$ z tytułu tego, że współczynnik tarcia przy stłaczaniu jest większy niż przy wtłaczaniu. Ww. zjawisko thumaczy się tym, że statyczny współczynnik tarcia (przy stłaczaniu) $\mu_{\mathrm{STAT}}$ jest większy niż współczynnik dynamiczny $\mu_{\text {DYN }}$ (przy wtłaczaniu). Ww. zjawisko wystąpi również wtedy, gdy pierścienie wewnętrzne będą osadzone na czopie osi za pomoca połączenia skurczowego (podgrzewanie pierścieni wewnętrznych łożysk). Należy pamiętać, że moment 
obrotowy $\mathrm{M}_{\mathrm{K}}$ (moment tarcia) został wyliczony dla sił statycznych nacisków kół, odpowiadających wagonowi w stanie ładownym. W rzeczywistości może przyjmować jeszcze większe wartości z uwagi na dodatkowy udział dynamiczny w naciskach kół.

Po poluzowaniu pierścieni wewnętrznych doszło do pęknięcia pierścienia wewnętrznego, co przedstawia fotografia, zamieszczona na rys.9.

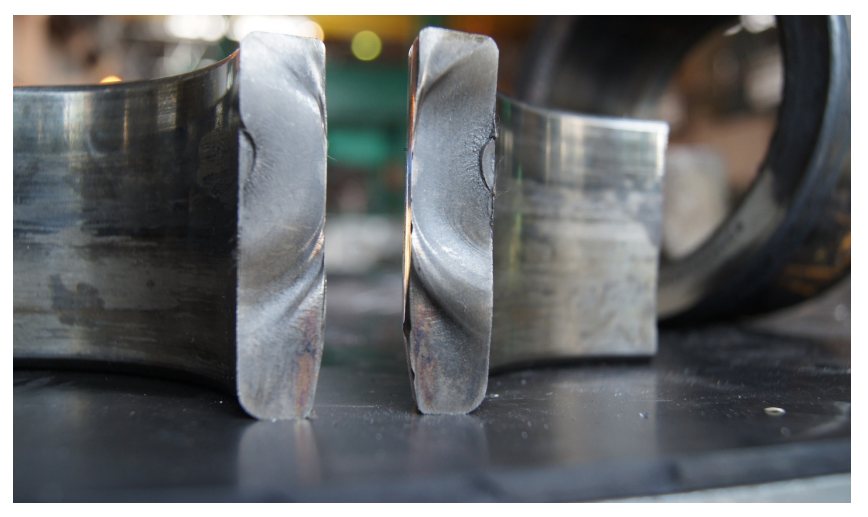

Rys.9. Pęknięcie pierścienia wewnętrznego łożyska osiowego

Z przedstawionej analizy obliczeniowej wynika, że bezpieczeństwo eksploatacyjne osi jest uzależnione od prawidłowego montażu oraz klasyfikacji łożysk do dalszej eksploatacji komercyjnej. Częste przypadki ukręcenia osi zestawu kołowego wskazują raczej na nie tyle zła jakość smaru, choć i tego nie można wykluczyć w badanych przypadkach, ale raczej na problematyczne używanie łożysk staroużytecznych. Poważne wątpliwości budzi składanie łożysk $\mathrm{z}$ różnych elementów, gdzie są wybite różne daty produkcji. Należy pamiętać, że ocena zmęczenia poszczególnych elementów łożyska jest bardzo trudna i nie można tego robić na podstawie metody wizualnej VT. Przy kwalifikacji poszczególnych elementów wózka zakwalifikowanie łożysk zwłaszcza $35 \div 45$ letnich jest operacją najtrudniejszą i wymagałoby nadzoru firm produkujących łożyska, a te ze zrozumiałych względów tego nie robią. Wydaje się, że konieczne jest stosowanie metod diagnostycznych dla wagonów towarowych, które z jednej strony przyczyniają się do wzrostu kosztów klejowego transportu szynowego ładunków, ale z drugiej strony gwarantują większe bezpieczeństwo eksploatacyjne.

\section{NOWOCZESNA METODA DIAGNOSTYCZ- NA ZWIEKSZAJĄCA BEZPIECZEŃSTWO WAGONÓW TOWAROWYCH}

Fraunhofer Institut für Betriebfestigkeit und Systemzuverlässigkeit (LBF) w Darmstadt opracował innowacyjną metodę, służącą długotrwałej kontroli zawieszeń wagonów towarowych. Układ pomiarowy jest przedstawiony na rys. 10 .

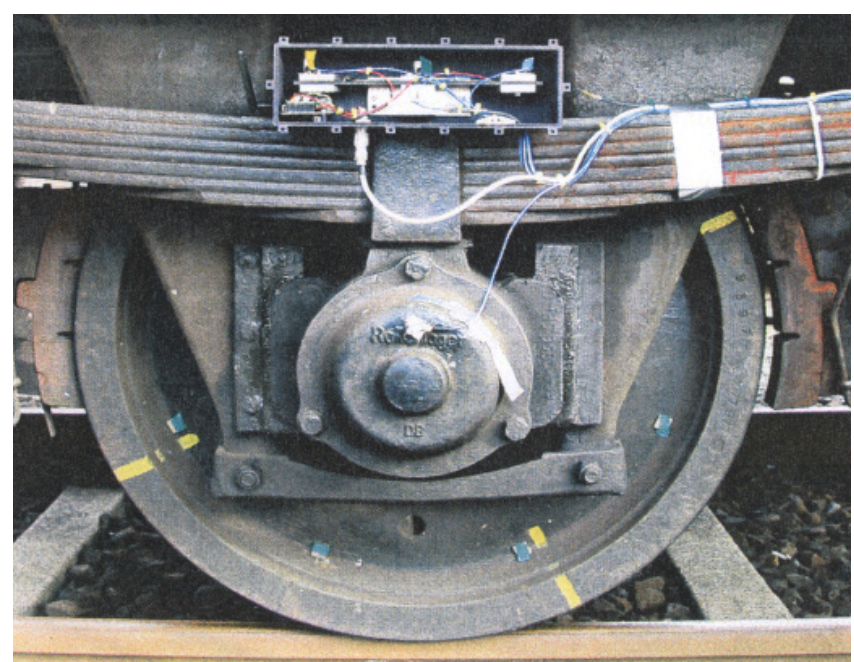

Rys.10. Układ pomiarowo-diagnostyczny dla zawieszeń wagonów towarowych, opracowany przez LFB w Darmstadt [10]

Największym problemem w wagonach towarowych jest brak energii elektrycznej, która mogłaby być zastosowana do zasilania układu pomiarowego. $\mathrm{Z}$ tego względu opracowano system „Energy-Harvesting”, który pozyskuje energię z pionowych ruchów układu zestawu kołowego, która $\mathrm{z}$ kolei jest przetwarzana przez czujniki piezolelektryczne. Na rys.10 jest przedstawiony układ sensorów, które są zamontowane w sposób sztywny na opasce resorowej. W wyniku tego zestaw kołowy oraz nawierzchnia kolejowa tworza układ drgający o częstotliwości własnej mniejszej od $0,1 \mathrm{kHz}$. Dane pomiarowe, rejestrowane przez sensory są przekazywane do wagonu bagażowego, w którym jest umieszczony komputer dokonujący oceny transmitowanych danych pomiarowych. System pomiarowy po udanych próbach stanowiskowych został wdrożony do wykrywania przegrzanych łożysk tocznych (maźnic) w trakcie eksploatacji komercyjnej. $\mathrm{W}$ dalszych planach transmisję danych planuje się przeprowadzić bezprzewodowo na lokomotywę. W dalszej perspektywie jako system diagnostyczny dla niezawodnej kontroli wagonów towarowych w pociagach jest przewidziany system zabezpieczenia ruchu pociagów ETCS poziomu 3.

\section{WNIOSKI}

Z pokazanych przykładowo analiz wynika, że problematyka bezpieczeństwa osi zestawów kołowych tocznych i napędnych jest wciąż aktualna. Wymagania sformułowane $w$ normach obliczeniowych PN-EN 13103+A1:2011 [12] i PN-EN 13104:2011 [13] sa bardziej rygorystyczne aniżeli w karcie UIC 515-3 [28], analogicznie jak $\mathrm{W}$ normie PN-EN 13261+A1:2011 [15] w stosunku do karty UIC 811-1 [29], PN-64/H-84027 [20], PN-91/H-84027/03[22] oraz PN-91/H-84027/03 [23]. Oś zaprojektowana zgodnie z przepisami i wykonana zgodnie z PN-EN 13261+A1:2011 [15] nie oznacza jeszcze, że 
bezpieczeństwo eksploatacyjne jest zachowane. W rzeczywistości o przydatności osi do eksploatacji komercyjnej decyduje stan techniczny osi, niezależnie od jej wieku. Wyznaczona granica zmęczenia dla stali EA1N wynosząca $200 \mathrm{MPa}$ dla zginania obrotowego powinna być zwiększana na drodze technologicznej, chociażby przez rolowanie (wałeczkowanie). Poglądy o szkodliwym wpływie rolowania, które pełni rolą umocnienia powierzchniowego $\mathrm{W}$ strefie przypowierzchniowej są kompletnie nieuzasadnione. Należy pamiętać, ze na stacjonarnych stanowiskach badawczych realizuje się tylko $10^{7}$ cykli zmęczeniowych, co jak potwierdza praktyka jest małą ilością w stosunku do rzeczywistych osiaganych $\mathrm{w}$ eksploatacji komercyjnej wynoszaceej $2 \times 10^{9}$ (zakres giga-cyklowy). Gwarancją osiagnięcia żywotności 40 lat (żywotność wymieniona dla całego układu biegowego wagonów towarowych w raporcie ORE/ERRI B12/Rp.14/D. Frage B12 [34] i większej jest prawidłowe utrzymanie osi, badania diagnostyczne, przeprowadzone przez wykwalifikowany personel zgodnie w wymaganiami EN473 [10] oraz kartą UIC 960 [32] stosowanie coraz bardziej zaawansowanych systemów diagnostycznych, wykrywających w porę zagrożenie związane z pęknięciem osi lub jej uszkodzeniem. Aby to osiagnąć należy zawsze eliminować zbędne ryzyko. Każdy wypadek kolejowy lub katastrofa powinna być potraktowana jak poważne ostrzeżenie i być początkiem inwestowania w badania diagnostyczne oraz wdrażanie systemów diagnostycznych, nie mówiąc już o tym że tego rodzaju działalność powinna mieć charakter prewencyjny. Warunkiem prawidłowego funkcjonowania osi podczas eksploatacji jest również prawidłowe wykonanie kół na zgodność z nowymi normami europejskimi tzn. PN-EN 13262+A1:2011 [16], PN-EN 13715:2008 [17] oraz PN-EN 13979-1:2007 [18] oraz kartą UIC 510-5 [27] oraz prawidłowe zmontowanie zestawu kołowego zgodnie z PN-EN 13260+A1:2011 [14] lub kartą UIC 813 [30].

\section{LITERATURA}

[1] Hochbein H.: Erhöhte Betriebssicherheit von Radsatzwellen durch Fest- und Glattwalzen. Eisenbahningenieur Nr. 10/2012

[2] Kocańda S. : Zmęczeniowe niszczenie metali. Wydawnictwo Naukowo-Techniczne. W-wa 1978.

[3] Sobaś M.: Diagnostyka osi zestawów kolowych ukladów biegowych pojazdów trakcyjnych i tocznych. Pojazdy Szynowe nr 4/2010

[4] Sobaś M.: Kryteria obiektywnej oceny prognozowanych stanów osi zestawów osi zestawów kołowych pojazdów trakcyjnych. Pojazdy Szynowe nr 1/2011.

[5] Sobaś M.: Zabiegi technologiczne zwiększajace żywotność osi zestawów kotowych. Pojazdy Szynowe nr 4/2011

[6] Sobaś M.: Przedsięwzięcia zwiększajace prognozowanq żywotność osi zestawów kołowych w skali Unii Europejskiej. Pojazdy Szynowe nr 2/2012.
[7] Sobaś M.: Czynniki konstrukcyjne $i$ technologiczne wplywajace na żywotność osi zestawów kołowych. Pojazdy Szynowe nr 3/2012.

[8] Stasiak L.: Doświadczalna determinacja charakterystyk wytrzymałości zmęczeniowej osi zestawów kołowych pojazdów szynowych. Rozprawy Nr 173. Poznań 1986.

[9] Tauscher H.: Dauerfestigkeit von Stahl und Gusseisen. 4-te neuaufbearbeitete Auflage, Leipzig 1982.

[10] Fraunhofer-Institut für Betriebsfestigkeit und Systemzuverlässigkeit in Darmstadt: Energieautarke Überwachung von Güterwagen. Elektrische Bahnen Nr. $11 / 2012$.

[11] EN 473: Kwalifikacja i certyfikacja personelu do badań nieniszczacych. Ogólne zasady.

[12\} PN-EN 13103+A2:2011: Kolejnictwo. Zestawy kotowe $i$ wózki. Osie zestawów kołowych tocznych. Zasady konstrukcji.

[13] PN-EN 13104+A1:2011: Kolejnictwo. Zestawy kołowe $i$ wózki. Osie zestawów kołowych napędnych. Zasady konstrukcji.

[14] PN-EN 13260+A1:2011: Kolejnictwo. Zestawy kotowe $i$ wózki. Zestawy kołowe. Wymagania dotyczace wyrobu.

[15] PN-EN 13261+A1:2011: Kolejnictwo. Zestawy kołowe i wózki. Osie. Wymagania dotyczqce wyrobu.

[16] PN-EN 13262+A1:2011: Kolejnictwo. Zestawy kołowe $i$ wózki. Koła. Wymagania dotyczqce wyrobu.

[17] PN-EN 13715:2008: Kolejnictwo. Zestawy kołowe $i$ wózki. Koła. Zewnętrzne zarysy wieńców kót.

[18] PN-EN 13979-1:2007: Kolejnictwo. Zestawy kołowe $i$ wózki. Koła monoblokowe. Procedura opuszczenia. Część 1: Koła kute i walcowane.

[19] PN-EN 15313:2010: Kolejnictwo. Wymagania eksploatacyjne dotyczace obstugi zestawów kołowych. Utrzymanie zestawów kolowych pojazdów w eksploatacji $i$ wyłaczonych z eksploatacji. .

[20] PN-64/H-84027: Stal dla kolejnictwa. Osie zestawów kołowych. Gatunki.

[21] PN-74/H-84041: Stal na łożyska toczne. Osie zestawów kołowych do pojazdów szynowych. Gatunki.

[22] PN-84/H-84027/03: Stal dla kolejnictwa. Osie zestawów kołowych do pojazdów szynowych. Gatunki.

[23] PN-91/H-84027/03: Stal dla kolejnictwa. Osie zestawów kołowych do pojazdów szynowych. Gatunki.

[24] PN-92/K-91048: Wagony towarowe. Osie zestawów kołowych.

[25] PN-93/H-94357: Stal i staliwo. Tablice porównawcze twardości określonej sposobem Rockwella, Vicekrsa, Brinella, Shore'a i wytrzymałość na rozciaganie.

[26] Karta UIC 510-1: Wagony towarowe. Układ biegowy-Normalizacja. 9-te wydanie z 1.01.1978. 14-ście zmian od 1.01.1980 do 1.01.1997.

[27] Karta UIC 510-5: Dopuszczenie kót monoblokowych -zastosowany dokument dla EN 13979-1.2-gie wydanie z maja 2007 roku.

[28] Karta UIC 515-3: Pojazdy kolejowe. Wózki-układy biegowe. Metoda obliczeń osi zestawów kołowych. 1sze wydanie z 1.07.1994

[29] Karta UIC 811-1: Warunki techniczne na dostawe osi zestawów kołowych dla nowobudowanych pojazdów trakcyjnych $i$ wagonów. 4-te wydanie z 1.01.1987 (karta unieważniona 2005 rok) 
[30] Karta UIC 813: Warunki techniczne na dostawe zestawów kołowych dla taboru trakcyjnego $i$ wagonów. 2-gie wydanie z grudnia 2003.

[31] Karta UIC 814: Warunki techniczne dotyczace homologacji oraz dostawy smarów przeznaczonych do smarowania maźnic tocznych pojazdów szynowych. 2-gie wydanie z 1.07.1988. errata z 1.07.1992.

[32] Karta UIC 960: Kwalifikacja i certyfikacja personelu odpowiedzialnego za prowadzenie badań nieniszczqcych elementów zespołów pojazdów szynowych $w$ procesie ich utrzymania.2-gie wydanie z grudnia 2001.
[33] OW-1166/1: Tymczasowe warunki techniczne na rolowanie osi zestawów kołowych oraz wagonów osobowych i towarowych. 1969.

[34] Raport ORE/ERRI B12/Rp.14/D: Frage B12. Vereinheitlichung der Güterwagen. StandardDrehgestell. Bericht Nr.14. Utrecht, listopad 1967.

[35] Raport ORE/ERRI B136/Rp.11/D: Zestawy kołowe z nasadzanymi tożyskami tocznymi. Konstrukcja, utrzymanie $i$ standaryzacja. Obliczenie osi zestawów kołowych dla wagonów towarowych $i$ osobowych. Utrecht, kwiecień 1979. 